\title{
Imagen, medium, cuerpo: un nuevo acercamiento a la iconología*
}

\author{
Hans BELTING \\ Traducción de Oscar Gómez
}

\section{1. ¿POR QUÉ ICONOLOGÍA?}

En su libro sobre iconología, W.J.T. Mitchell (1986), explicó el problema de la iconología usando los términos imagen, texto e ideologia ${ }^{1}$. En mi nuevo libro sobre Antropología de la imagen (Bild-Anthtroplogie), también uso una tríada de términos en la que, por razones obvias, el de imagen permanece, pero enmarcado ahora por los términos medium y cuerpo $^{2}$. Esta elección no pretende invalidar la perspectiva de Mitchell. Más bien, define otro enfoque entre los múltiples intentos para comprender las imágenes en su amplio espectro de significados y propósitos. Desde mi punto de vista, sin embargo, su significado se vuelve accesible solo cuando tomamos en cuenta otros determinantes no icónicos tales como, en un sentido muy amplio, el medium y el cuerpo. Medium aquí debe entenderse no tanto en el sentido habitual como en el sentido de un agente a través del cual se transmiten las imágenes, mientras que cuerpo se refiere tanto al cuerpo performativo como al receptor del que las imágenes dependen tanto como de su medium. No hablo de medium como tal, por supuesto, ni de cuerpo como tal. Ambos han cambiado continuamente (lo que nos permite hablar tanto de una historia de las tecnologías visuales, así como de una historia de la percepción) pero en su presencia siempre cambiante han mantenido su lugar en la circulación de imágenes.

Las imágenes no están ni únicamente en la pared (o en una pantalla), ni sólo en nuestra cabeza. No existen por sí mismas, sino que suceden; toman posición sean imágenes en movimiento (lo que sería muy obvio), o no. Suceden a través de transmisión y percepción. La lengua alemana ignora la diferencia entre picture e image, lo que, aunque parezca ser una falta de distinción, conecta muy bien las imágenes

\footnotetext{
* Este artículo apareció publicado en Critical Inquiry, 2005, 31, 2, pp. 302-319.

1 Ver W.J.T. Mitchell, Iconology: Image, Text. Ideology (Chicago, 1986).

2 El presente ensayo es un intento de resumir y extender la discusión sobre mi libro Bild-Anthropologie: Entwürfe für eine Bildwissenschaft (Munich,2001). En castellano, el libro Antropología de la imagen ha sido editado por Katz en 2007.
} 
físicas y los artefactos físicos entre sí, lo que es también mi intención con este ensayo. Puede ser, sin embargo, causa de desacuerdo entre nosotros el intentar identificar las imágenes en una historia continuada y que no ha terminado con el nacimiento de la era digital. Solo si uno comparte esta posición, verá que mi acercamiento a la iconología tiene sentido. De lo contrario, cualquier intento quedaría en manos de una arqueología de las imágenes cuyo significado no podría aplicarse a la experiencia contemporánea. Me gusta insistir en esta predisposición, puesto que es la única razón de la generalidad de mi propuesta. En vez de discutir la cultura contemporánea, todavía me entretiene el idealismo de concebir una historia de las imágenes en curso. Por esta razón, propongo un nuevo tipo de iconología que sirva para vincular pasado y presente de la vida de las imágenes y que, por lo tanto, no esté limitada al arte (como lo estaba en la iconología de Panofsky, que aquí dejo a un lado) ${ }^{3}$.

Puede ser menos discutible salvar la diferencia entre arte y no-arte en el ámbito de las imágenes. Tal diferencia, de todos modos, se puede mantener durante la era moderna solo cuando el arte, del que ya no se espera que sea narrativo en el viejo sentido, mantiene la distancia de una estética autónoma y evita la información y el entretenimiento, por mencionar solo dos de los efectos de las imágenes. Todo el debate entre cultura alta y baja ha descansado en este dualismo tan familiar, cuyo objetivo, mientras tanto, merece la pena volver a recordar. Hoy en día, las artes visuales retoman de nuevo la cuestión de la imagen, que durante tanto tiempo se apartó de las teorías dominantes de arte. Es el arte contemporáneo el que analiza de manera más radical la violencia o la banalidad de las imágenes ${ }^{4}$. En una especie de práctica visual de la iconología, los artistas suprimen la distinción recibida entre teoría de la imagen y teoría del arte, siendo esta última una noble subcategoría de la primera. En la actualidad se hace urgente una iconología crítica porque nuestra sociedad está expuesta al poder de los medios de comunicación de masas de una forma sin precedentes.

El discurso actual sobre las imágenes adolece de una gran cantidad de concepciones diferentes, e incluso contradictorias, sobre lo que son las imágenes y sobre cómo funcionan. La semiología*, por poner un ejemplo, no permite que las imágenes existan más allá del territorio controlable de los signos, las señales y la comunicación. La Teoría del arte tiene otras reservas, igualmente fuertes, sobre cualquier teoría de la imagen que amenace el antiguo monopolio del arte y su objeto exclusivo. Las ciencias - en particular, la neurobiología - examinan la actividad de percepción del cerebro como un fenómeno de "representación interna", mientras que la percepción de sus instrumentos generalmente recibe poca atención en este contexto. Yo he propuesto recientemente un enfoque antropológico, entendiendo la antropología en el sentido europeo que la diferencia de la etnología. Según este enfoque, las

\footnotetext{
${ }^{3}$ Ver Edwin Panofsky, Estudios sobre iconología (Madrid, Alianza 1971).

${ }^{4}$ Ver High and Low, ed. James Leggio (catálogo de la exhibición, Museum of Modern Art, New York, 7 Oct. 1990-15 Ene. 1991).

${ }^{*}$ Nota del traductor: Nótese que al autor se muestra crítico con la semiología, pero nada dice de una teoría semiótica. A nuestro parecer, numerosas consideraciones utilizadas tanto por la semiótica de la cultura como por el análisis semiótico de textos visuales pueden establecer un diálogo muy productivo con los argumentos que se defienden en estas páginas.
} 
representaciones internas y externas, o imágenes mentales y físicas, pueden ser consideradas como caras de una misma moneda. La ambivalencia entre las imágenes endógenas y las imágenes exógenas, que interactúan en muchos niveles diferentes, es inherente a la práctica de la imagen de la humanidad. Los sueños y los iconos, como Marc Augé las llama en su libro La guerra de los sueños, son interdependientes $^{5}$. La interacción entre imágenes mentales e imágenes físicas es un campo todavía poco explorado, que se refiere a la política de las imágenes tanto como a lo que los franceses llaman el imaginaire de una sociedad determinada.

\section{MEDIUM E IMAGEN}

El qué de una imagen (la cuestión de lo que la imagen desempeña como imagen o a lo que se refiere como imagen) es dirigido por el cómo en que se transmite su mensaje. De hecho, el cómo es a menudo difícil de distinguir del qué; es la esencia misma de una imagen. Pero el cómo, a su vez, está en gran medida formado por el medium visual dado en el que reside una imagen. Cualquier iconología actual debe discutir tanto la unidad como la distinción entre imagen y medium, entendiendo este último en el sentido de un medium portador o huésped. No hay imágenes visibles que nos lleguen sin mediación. Su visibilidad se basa en su medialidad particular, que controla su misma percepción y dirige la atención del espectador. Las imágenes físicas son físicas debido a los media que utilizan, pero lo físico ya no puede explicar sus tecnologías actuales. Las imágenes siempre se han basado en una técnica determinada para su visualización. Cuando distinguimos un lienzo de la imagen que representa, se presta atención a uno o a la otra, como si fueran distintas, pero no lo son; se separan solo cuando estamos dispuestos a separarlos con nuestra mirada. En este caso, disolvemos la "simbiosis" a través de nuestra percepción analítica. Incluso recordamos las imágenes por la mediación específica con la que nos las encontramos por primera vez, y recordar significa primero desencarnarlas de sus medios originales y luego darles un nuevo cuerpo en nuestro cerebro. Los visual media compiten, por lo que parece, con las imágenes que transmiten. Tienden, tanto a disimularse a sí mismos como a reclamar la atención principal. Cuanto más nos fijamos en un medium, menos se pueden ocultar sus estrategias. Cuanto menos nota tomamos de un medium visual, más nos concentramos en la imagen, como si las imágenes viniesen por sí mismas. Cuando el medio visual se hace auto-referencial, se vuelve en contra de sus imágenes y roba su atención 6 .

La medialidad, en este sentido, no es reemplazable por la materialidad de las imágenes como ha sido costumbre en la vieja distinción entre forma y materia. La materialidad sería, en cualquier caso, un término inapropiado para los medios de hoy en día. Un medio es forma, o transmite la forma misma en que percibimos las imágenes. Pero la medialidad tampoco puede ser reducida a la tecnología. Los medios

\footnotetext{
5 Ver Marc Augé, La Guerre des rêves: Exercises d'ethno-fiction (Paris, 1997); traducido al castellano como La Guerra de los sueños: ejercicios de etno-ficción (Gedisa, Madrid 2008).

6 Ver Belting, Antropología de la imagen, pp. 29-38.
} 
usan técnicas simbólicas a través de las cuales transmiten las imágenes y las graban en la memoria colectiva. La política de las imágenes se basa en su medialidad, ya que la medialidad es generalmente controlada por las instituciones y sirve a los intereses del poder político (aun cuando, tal como lo experimentamos en la actualidad, se esconde detrás de una transmisión aparentemente anónima). La política de las imágenes necesita un medio para convertir una imagen (image) en una imagen (picture).

Distinguimos fácilmente imágenes antiguas e imágenes nuevas, requiriendo ambas de un tipo diferente de atención como resultado de sus diferentes media pictóricos. También distinguimos entre media privados y públicos, que tienen un impacto diferente sobre nuestra percepción y que pertenecen a los diferentes espacios que los crean, o que son creados por ellos. Es verdad que experimentamos imagen y medium como inseparables y que reconocemos a una en el otro. Y sin embargo, las imágenes no son producidas únicamente por su medium, como la euforia tecnológica a veces pretende que sea, pero se transmiten de esta manera, lo que significa que las imágenes no se pueden describir con un enfoque exclusivamente mediológico de manera satisfactoria.

\section{MEDIUM Y CUERPO}

El uso de los visual media juega un papel central en el intercambio entre la imagen y el cuerpo. Los media forman el eslabón perdido entre uno y otro ya que canalizan nuestra percepción, y por lo tanto, nos impiden confundirlos ya sea tomándolos como cuerpos reales o, en el extremo opuesto, como meros objetos o máquinas. Es nuestra propia experiencia corporal la que nos permite identificar el dualismo inherente en los visual media. Sabemos que todos tenemos o que todos poseemos imágenes, que viven en nuestros cuerpos o en nuestros sueños y que, para aparecer, esperan a ser convocadas por nuestros cuerpos. Algunos idiomas, como el alemán, distinguen un término para la memoria como un archivo de imágenes (Gedächtnis), de un término para la memoria como una actividad, es decir, como nuestro recuerdo de imágenes (Erinnerung). Esta distinción significa tanto que poseemos como que producimos imágenes. En cada caso, los cuerpos (es decir, el cerebro) funcionan como un medium vivo que nos hace percibir, proyectar o recordar imágenes y que también permite a nuestra imaginación censurarlas o transformarlas.

La medialidad de las imágenes va mucho más allá del ámbito visual, hablando con propiedad. El lenguaje transmite la imaginería verbal cuando transformamos las palabras en nuestras propias imágenes mentales. Las palabras estimulan nuestra imaginación mientras que la imaginación, a su vez, las transforma en las imágenes que significan. En este caso, es el lenguaje el que sirve como un medium para la transmisión de imágenes. Pero aquí, también, necesita nuestro cuerpo para completarlas con la experiencia personal y el significado; esta es la razón por la que la imaginación se ha resistido tan a menudo a cualquier control público. En el caso de la imaginería verbal, no obstante, estamos bien entrenados para distinguir imagen de medium, mientras que en el caso de imágenes físicas o visibles no lo estamos. $\mathrm{Y}$, sin 
embargo, la apropiación de imágenes en ambas situaciones es menos distinta de lo que nuestra educación nos permite creer.

La distinción entre lenguaje y escritura también se aplica a mi caso. La lengua hablada está vinculada a un cuerpo, que, como medium vivo, habla, mientras que el lenguaje escrito se retira del cuerpo y se refugia en un libro o en un monitor, en el que no escuchamos una voz, pero leemos un texto. El acto de lectura depende de nuestra distinción adquirida entre palabra y medium, lo que, de alguna manera, también se aplica al acto de visualización de imágenes, aunque por lo general no seamos conscientes de esos mecanismos. De hecho, también, en cierto sentido, leemos imágenes visuales cuando las distinguimos de su medium. Los visual media, hasta cierto punto, coinciden con el lenguaje escrito, pero no han sido objeto del tipo de codificación que tiene la escritura. Nuestro oído también participa en la apropiación de imágenes cuando vienen con sonido y por lo tanto ofrece un agente inesperado o compañero para percibir imágenes. El cine sonoro fue el primer medio visual en explotar nuestra capacidad de vincular íntimamente el sonido y la vista. Se da la circunstancia de que la música de acompañamiento, que ya aportaba el cine mudo con un pianista en la sala, también cambia la experiencia de las mismas imágenes, en el sentido de que su apariencia cambia cuando una banda sonora diferente da forma a la impresión que ejerce sobre nuestros sentimientos.

La auto-percepción de nuestros cuerpos (la sensación de que vivimos en un cuerpo) es una condición previa indispensable para la invención de los media, que pueden ser llamados cuerpos técnicos o artificiales diseñados para sustituir órganos a través de un procedimiento simbólico. Las imágenes viven, podemos concluir, en sus media, tanto como nosotros vivimos en nuestros cuerpos. Desde muy temprano, los seres humanos se vieron tentados a comunicarse con las imágenes como si fueran cuerpos vivos y también a aceptarlas en el lugar de esos cuerpos. En ese caso, en realidad animamos sus media con el fin de experimentar las imágenes como vivas. Esta animación es nuestra responsabilidad, al igual que el deseo de nuestra mirada es responsabilidad de un medium dado. Un medio es el objeto, una imagen, el objetivo de la animación. La animación, como actividad, describe el uso de imágenes mejor que la percepción. Esto último es válido tanto para nuestra actividad visual en general como en la vida cotidiana. Los artefactos visuales, sin embargo, dependen de un tipo específico de percepción (percepción de las imágenes como si fueran cuerpos o en nombre de cuerpos), es decir, la percepción de un tipo simbólico. El deseo de imágenes precedió a la invención de sus respectivos media.

\section{IMAGEN Y MUERTE}

Esta distinción necesita una breve digresión. El tema de la imagen y de la muerte me hizo embarcarme en el tipo de iconología que estoy presentando aquí. Aunque nuestro consumo de imágenes en la actualidad ha aumentado a un grado sin precedentes, nuestra experiencia con las imágenes de los muertos ha perdido su importancia en su conjunto. Así, por lo tanto, nuestra familiaridad con las imágenes casi parece invertirse. Siempre que las sociedades arcaicas veían imágenes, veían imá- 
genes de los muertos, que ya no vivían en sus cuerpos, o imágenes de dioses, que vivían en otro mundo. La experiencia de la imagen en aquellos tiempos estaba vinculada a rituales tales como el culto a los muertos, a través del cual los muertos se reintegraban en la comunidad de los vivos ${ }^{7}$.

Parece oportuno recordar las condiciones que contribuyeron a la introducción de imágenes físicas para el uso humano. Entre tales condiciones, el culto a los muertos figura como uno de los más antiguos y más significativos. Las imágenes, preferiblemente las de tres dimensiones, reemplazaron a los cuerpos de los muertos, que habían perdido su presencia visible junto con sus cuerpos. Las imágenes, en nombre del cuerpo que faltaba, ocuparon el lugar abandonado por la persona que había muerto. Una comunidad determinada se sentía amenazada por la brecha causada por la muerte de uno de sus miembros. Los muertos, como resultado, se mantenían presentes y visibles entre los vivos a través de sus imágenes. Pero las imágenes no existían por sí mismas. A su vez, necesitaban de una forma de encarnación, lo que significa que necesitaban de un agente o medium que pareciese un cuerpo. Esta necesidad fue satisfecha con la invención de los visual media, que no solo encarnaban a las imágenes sino que parecían cuerpos vivos a su modo. Incluso cráneos reales fueron reanimados como imágenes vivas con la ayuda de conchas insertadas como nuevos ojos y una capa de arcilla como una nueva piel sobre el rostro, tal como encontramos en la cultura neolítica de Oriente Próximo en el año 7000 a.C. Tanto la imagen como el medium viven de una analogía corporal. Podríamos hablar, en términos de Baudrillard, de un "intercambio simbólico" entre un cadáver y una imagen en vivo $^{8}$. La constelación triádica en la que el cuerpo, el medium y la imagen se interconectan, aparece aquí con toda claridad. La imagen de los muertos, en el lugar del cuerpo que falta, el cuerpo artificial de la imagen (el medium), y el cuerpo en busca de los vivos interactuaron en la creación de la presencia icónica frente a la presencia corporal.

\section{ICONOCLASIA}

El vínculo entre las imágenes mentales y las imágenes físicas con las que traducimos quizás pueda explicar el entusiasmo inherente a cualquier iconoclasia de destruir imágenes físicas. Los iconoclastas realmente querían eliminar imágenes del imaginario colectivo, pero en realidad solo pudieron destruir sus media. Lo que el pueblo ya no podía ver, se esperaba, tampoco podía vivir en su imaginación. La violencia contra las imágenes físicas ayudó a extinguir las imágenes mentales. El control sobre los media públicos es un principio fundamental en la prohibición de las imágenes, de la misma forma en que ese control había forzado, en un comienzo, su introducción. Ambos actos son violentos en un grado similar porque cualquier cir-

\footnotetext{
7 Ver ibid., cap. 5 ("Imagen y muerte: La representación corporal en las culturas tempranas [con un epílogo sobre fotografía]"), pp. 177-232.

8 Ver Jean Baudrillard, L'Echange symbolique et la mort (París, 1976); traducido bajo el título El intercambio simbólico y la muerte por Carmen Rada (Caracas, Monte Ávila 1980).
} 
culación de este tipo de imágenes se basa en la violencia abierta o secreta. La iconoclasia hoy, cuando las imágenes son simplemente retiradas de su circulación en televisión o en la prensa, puede ser más discreta, pero nunca tiene como objetivo la eliminación de su visibilidad pública. Desde un punto de vista actual, la destrucción de los monumentos soviéticos e iraquíes (como cualquier monumento, fueron visual media en su forma más oficial) fue igualmente anacrónica, ya que tales monumentos representaban en sí mismos el anacronismo de la escultura pública y por lo tanto se prestaban fácilmente a la venganza pública y la destrucción física en el sentido antiguo. Las imágenes oficiales, hechas con la intención de instaurarse en la memoria colectiva, desencadenaron la iconoclasia como una práctica de liberación simbólica. Más sutil fue la costumbre de denunciar las imágenes como materia muerta o superficies ciegas que, se decía, pretendían en vano refugio a las imágenes. Esta estrategia pretendía denunciar a diversos media, que una vez privados de sus imágenes, se convirtieron en superficies vacías o mera materia, perdiendo así su propósito9.

Algunas culturas antiguas se entretenían con la práctica de consagrar sus imágenes de culto antes de tomarlas en uso ritual. En aquel tiempo, la consagración era necesaria para convertir objetos en imágenes. Sin tal ritual de consagración, las imágenes no eran más que objetos y por lo tanto eran considerados como inanimadas. Solo a través de la animación sagrada podrían estas imágenes ejercer el poder y su materia convertirse en medium. La creación de este tipo de imágenes, en primer lugar, las llevaba a cabo un escultor, pero del resto se encargaba un sacerdote. Incluso este procedimiento, que parece magia obsoleta, ya implicaba una distinción entre imagen y medium y necesitaba de un sacerdote para convertir un simple objeto en un medium. También nos dice que las imágenes siempre implicaron vida (de hecho, es nuestra propia vida la que se proyecta en ellas), mientras que a los objetos se les consideraba como muertos. El ritual de "apertura de la boca" del antiguo Egipto se refleja en la historia bíblica de la creación de Adán, que primero fue moldeado de arcilla y, después, animado. La narración bíblica tiene una base tecnomórfica porque refleja las prácticas en el taller de un escultor. En las culturas avanzadas, la animación ya no sigue siendo la tarea de un sacerdote, pero esperamos que el artista (y, hoy en día, la tecnología) simule la vida a través de imágenes en vivo. Sin embargo, la transformación de un medium en imagen sigue necesitando nuestra propia participación ${ }^{10}$.

\section{SOMBRAS DIGITALES}

Nuestra admiración actual por la tecnología ha sustituido al antiguo significado de habilidad artística. Ya no es el arte, sino la tecnología la que se ha hecho cargo de la mimesis de la vida. Sus analogías corporales evocan al espejo y a la sombra, que una vez fueron medios arquetípicos para la representación de cuerpos. La sombra

9 Ver Iconoclash, Bruno Latour y Peter Weibel, eds., (Karlsruhe, 2002).

10 Ver Antropología de la imagen, pp. 163-177. 
proyectada, que inspiró el relato de la muchacha de Corinto de Plinio, y la superficie del agua, que inspiró la historia de Narciso, deben considerarse como media naturales de la mirada ${ }^{11}$. Pero el paso hacia los media técnicos fue abrupto. En Corinto, la niña necesitaba una pared como soporte medial con el fin de delinear la sombra proyectada de su amante. La reflexión del agua, por el contrario, pronto fue reemplazada por el reflejo de los cuerpos en los espejos de metal antiguos. Los visual media no solo actúan como prótesis del cuerpo, sino también sirven para reflejar el cuerpo, que se presta a la a su propia auto-inspección. Las tecnologías más avanzadas de la actualidad simulan cuerpos bajo la apariencia de sombras fugaces, o de insustanciales imágenes en el espejo, de las que se espera que nos liberen de las leyes de la gravedad a las que estamos sujetos en el espacio empírico.

Los media digitales reintroducen la analogía del cuerpo a través de su negación. La pérdida del cuerpo ya frecuentó las fantasías del espejo del siglo XIX, cuando el doppelgänger dejó de obedecer a su espectador y abandonó la mímesis del cuerpo reflejado. Las imágenes digitales se dirigen normalmente a la imaginación de nuestros cuerpos y cruzan la frontera entre imágenes visuales e imágenes virtuales, imágenes vistas e imágenes proyectadas. En este sentido, la tecnología digital persigue la mímesis de nuestra propia imaginación. Las imágenes digitales inspiran imágenes mentales, tanto como se inspiran en las imágenes mentales y su flujo libre. Se anima a las representaciones externas e internas a fusionarse.

La experiencia de las imágenes digitales supera su lógica intrínseca como herramientas de la tecnología. Bernard Stiegler, en su ensayo sobre la imagen discreta ("discreta" en el sentido científico de una imagen discontinua y codificada digitalmente), propuso la distinción entre percepción analítica y percepción sintética: analítica con respecto a la tecnología o medium y sintética con respecto a la imagen mental que resulte de nuestra percepción. Sintético y síntesis, como términos, son apropiados para describir la formación de una imagen en nuestro cerebro. Esto implica, en primer lugar, el análisis de un medium dado y, después, la interpretación del mismo con la imagen que transmite. Nuestras imágenes, dice Stiegler, no existen por sí mismas o de sí mismas. Viven en nuestra mente como la "huella y la inscripción“ de imágenes que se ven en el mundo exterior. Los media tienen constantemente éxito en el cambio de nuestra percepción, pero todavía somos nosotros los que producimos las imágenes ${ }^{12}$.

Imagen y medium no permiten el mismo tipo de narrativa en la descripción de su historia. Una historia en un sentido literal sólo se aplica a las tecnologías visuales; las imágenes resisten cualquier historia lineal, ya que no están sujetas al progreso en la misma medida. Las imágenes pueden ser viejas, incluso cuando resurgen en los nuevos media. También sabemos que envejecen de manera diferente de la que enve-

11 Sobre el relato de Plinio, ver The Elder Pliny's Chapters on the History of Art, trad. Katherine JexBlake (Chicago, 1968), cap. 35; sobre la sombra y la pintura en Corinto, ver ibid., cap. 151, y Robert Rosenblum, "The Origin of Painting: A Problem in the Iconography of Romantic Classicism" en Art Bulletin 39, dic.1957: 279.

12 Ver Bernard Stiegler, "La imagen discreta" en Derrida y Stiegler, Ecografias de la televisión, trad. Horacio Pons (Buenos Aires, Edueba, 1998), pp.145-63. 
jecen los media. Generalmente se espera que los media sean nuevos, mientras que las imágenes se mantienen vivas aún siendo viejas y cuando resurgen con los nuevos media. Existe una pequeña dificultad en la reconstrucción de la trayectoria de las imágenes, que han emigrado durante varias etapas históricas que implican a diferentes media. Las imágenes se asemejan a nómadas en el sentido de que residen en un medium tras otro. Este proceso de migración ha tentado a muchos estudiosos a reducir su historia a una mera historia de los media, reemplazando así la secuencia de la imaginación colectiva por la evolución de la tecnología visual. Los autores americanos, como Regis Debray ha señalado en su libro Transmettre, suelen favorecer un discurso que privilegia a la tecnología a expensas de la política. La política de las imágenes, de hecho, supera la mera explotación de los visual media. Debray también insiste en el término transmisión en lugar de comunicación, puesto que la transmisión implica que alguien que quiera ejercer el poder y controlar la circulación de imágenes ${ }^{13}$.

La representación y la percepción interactúan estrechamente en cualquier política de las imágenes. Ambas están cargadas de una energía simbólica que se presta fácilmente al uso político. La representación está destinada sin ninguna duda a gobernar sobre la percepción, pero la simetría entre los dos actos no es mi mucho menos cierta. No hay automatismo en lo que percibimos y en cómo lo percibimos a pesar de todos los intentos por demostrar lo contrario. La percepción también puede llevarnos a resistir a las pretensiones de la representación. La destrucción de imágenes oficiales en este sentido es solo la punta del iceberg; es sólo en su superficie, alcanzando solo a la destrucción de los media de acogida de las imágenes, como esos media se consideraban mal utilizados, es decir, utilizados por la autoridad equivocada ${ }^{14}$.

\section{UN MEDIUM VIVO}

Imagen y medium están vinculados con el cuerpo, el tercer parámetro a considerar. El cuerpo siempre se ha mantenido igual y, precisamente por esta razón, ha sido sometido a un cambio constante con respecto a su concepción, así como a su auto percepción. La brecha entre la certeza de su presencia física y la incertidumbre de su significado nunca se cierra. Los cuerpos están fuertemente influenciados por su historia cultural y por lo tanto, nunca dejarán de estar expuestos a la mediación a través de su entorno visual. Por esto, los cuerpos no pueden considerarse invariables y no resisten el impacto del cambio de las ideas en la experimentación de los mismos. Pero son más que meros destinatarios pasivos de los medios visuales que les dieron forma. Su actividad es fundamental para experimentar los visual media.

La percepción, por sí sola, no explica la interacción de cuerpo y medium que tiene lugar en la transmisión de imágenes. Las imágenes, como ya he dicho, suceden, o se negocian, entre los cuerpos y los media. Los cuerpos controlan el flujo

13 Ver Regis Debray, Transmettre (Paris, 1997); traducido al castellano como Transmitir (Manantial, Buenos Aires 1997).

14 Sobre la representación, ver Christopher Prendergast, The Triangle of Representation (New York, 2000). 
de imágenes a través de la proyección, la memoria, la atención, o la indiferencia. Los cuerpos privados o individuales también actúan como cuerpos públicos o colectivos en una sociedad determinada. Nuestros cuerpos portan siempre una identidad colectiva, ya que representan una cultura determinada como resultado de la etnia, la educación y un entorno visual particular. Los cuerpos representantes (representing bodies) son aquellos que se representan a ellos mismos, mientras que los cuerpos representados (represented bodies) son imágenes separadas o independientes que representan cuerpos. Los cuerpos realizan y ejecutan imágenes (de ellos mismos o incluso contra sí mismos) y también perciben imágenes del exterior. En este doble sentido, son media vivos que trascienden las capacidades de sus media protésicos. A pesar de su marginalización, tan à la mode, defiendo su causa como indispensable para cualquier iconología.

Platón, el primer mediólogo, se opuso firmemente a la escritura como un peligro para el cuerpo como memoria viva y, en contraste, definió como muertas a las memorias técnicas, como el alfabeto. Lo que aquí importa no son sus conclusiones, que fueron ya un anacronismo en su propio tiempo, sino su válida distinción entre dos tipos de medium, cuerpos que hablan y el lenguaje escrito, por recordar su argumento más familiar. Con respecto a la memoria, introdujo una distinción análoga entre cuerpos vivos e imágenes sin vida, unos capaz de recordar a los mismos muertos y las otras solo de representarlos ${ }^{15}$. Las imágenes físicas, en su opinión, solo duplican la muerte, mientras que las imágenes de nuestra propia memoria traen a los muertos a una nueva vida. En apoyo de esta distinción, conscientemente rechazó cualquier imagen material de los muertos y desacreditó a todas las imágenes como mera ilusión. El hecho de desbaratar el significado de las imágenes de los muertos, las excluiría para siempre de la filosofía occidental. Sin embargo, desarrolló una teoría más poderosa, definiendo el cuerpo como un medium vivo ${ }^{16}$.

Las imágenes mentales y físicas se fusionarán, siempre y cuando sigamos colocando a las imágenes en el ámbito de la vida y considerando vivos a los media a través de su imágenes. La obsesión contemporánea por las imágenes en directo en este sentido es la prueba suficiente. Las imágenes se han imbuido del movimiento y del habla, como en las películas o en la transmisión por televisión. En cualquier caso, relacionamos estrechamente las imágenes con nuestra propia vida y esperamos que interactúen con nuestros cuerpos, con los que las percibimos, las imaginamos y las soñamos. Pero la noción incierta del cuerpo, cuya crisis actual es evidente, nos ha llevado a extrapolar la expectativa de vida e investir a los cuerpos artificiales, frente a los cuerpos vivos, con una vida superior. Esta tendencia ha causado una gran confusión, dando la vuelta a la función misma de los visual media. De este modo, los media contemporáneos se han visto investidos de un poder paradójico sobre nuestros cuerpos, que se sienten derrotados en su presencia.

15 Ver Iris Därmann, Tod und Bild: Eine phänomenologische Mediengeschichte (Munich, 1995).

${ }^{16}$ Ver Belting, Antropología de la imagen cap. 5, sec. 8 ("La crítica de Platón a las imágenes"), pp. 214-217. 


\section{PRESENCIA ICÓNICA}

Las imágenes viven tradicionalmente de la ausencia del cuerpo, ya sea temporal (es decir, espacial) o, en el caso de la muerte, final. Esta ausencia no significa que las imágenes revoquen los cuerpos ausentes y los hagan volver. Más bien, sustituyen la ausencia del cuerpo con un tipo diferente de presencia. La presencia icónica todavía mantiene la ausencia de un cuerpo y lo convierte en lo que debemos llamar ausencia visible. Las imágenes viven de la paradoja de representar la presencia de una ausencia o viceversa (lo que también se aplica a la telepresencia en los media actuales). Esta paradoja, a su vez, se basa en la práctica de relacionar la presencia con la visibilidad. Los cuerpos están presentes porque son visibles (incluso al teléfono la otra persona está ausente). Cuando cuerpos ausentes se hacen visibles en imágenes, utilizan una visibilidad vicaria. Recientemente, esta noción ha sido la causa de la violenta contradicción de las teorías posthumanas, que nos impulsan a reemplazar dicha categoría por la mera noción de reconocimiento de patrones, preferiblemente en un sentido técnico ${ }^{17}$.

Estamos dispuestos a delegar la visibilidad del cuerpo a unas imágenes que, sin embargo, necesitan de un medium apropiado para hacerse visibles. Las imágenes están presentes debido a, y a través de sus media, pero representan una ausencia de la que son imagen. El aquí y ahora de una imagen, su presencia, en un cierto grado se basa en el medium visual en el que reside (incluso las imágenes de nuestros sueños utilizan nuestro cuerpo como medium). Las imágenes externas, por así decirlo, necesitan un cuerpo sustituto, al que llamamos medium. Pero la ambivalencia entre ausencia y presencia también invade la constelación de imagen y medium. Los medios están presentes como si fueran cuerpos, mientras que las imágenes no. Por lo tanto, podría reformularse la presencia de una ausencia, que sigue siendo la definición más elemental de las imágenes, de la siguiente manera: las imágenes están presentes en los media, pero representan una ausencia, que hacen visible. La animación significa que abrimos la opacidad de un medium para la transmisión de imágenes.

Desde la época de Galileo o de Röntgen, sin embargo, estamos familiarizados con otro tipo de ausencia, a saber, lo ausente para la vista y no la ausencia como tal. Los mundos del telescopio o los representados por rayos $\mathrm{X}$ nunca son visibles de la forma en que lo son los cuerpos humanos. Están presentes y sin embargo permanecen invisibles. Necesitamos medios visuales con su función protésica cuando queremos ver un microcosmos o el espacio exterior. Pero incluso en este caso se reemplazan los objetivos remotos de la visión (permítanme llamarlos cuerpos) por imágenes que no solo usan la tecnología sino que dependen totalmente de ella a fin de presentarlos ante nuestra vista. Este tipo de imágenes tienen incluso mayor importancia de la que tendrían en una situación normal. A menudo olvidamos que solo simulan la inmediatez de la percepción, que parece ser la nuestra, pero que, de hecho, es suya. Los debates recientes en la revista Imaging Science y en otros luga-

\footnotetext{
17 Ver N. Katherine Hayles, How We Became Pasthuman: Virtual Bodies in Cybernetics, Literature, and Informatics (Chicago, 1999).
} 
res han abandonado tardíamente la ilusión en la creencia de que las imágenes científicas son miméticas en el sentido de que queremos y necesitamos que lo sean. De hecho, están organizadas específicamente para abordar nuestra ingenuidad visual y así servir a nuestros cuerpos, como las imágenes han hecho siempre.

Las nuevas tecnologías de la visión, sin embargo, han introducido una cierta abstracción en nuestra experiencia visual, ya que no somos capaces de controlar la relación existente entre una imagen y su modelo. Por lo tanto, confiamos más en las máquinas visuales que en nuestros propios ojos, como consecuencia de lo cual su tecnología se encuentra con una fe ciega literal. Los media aparecen menos como un intermediario que como sistemas auto-referenciales, que parecen marginarnos en el punto final de la recepción. La transmisión es más espectacular que lo que se transmite. Y, sin embargo, la historia de las imágenes nos enseña a no abandonar nuestras creencias sobre cómo funcionan las imágenes. Todavía estamos confinados a nuestros cuerpos individuales, y aún deseamos imágenes que tengan sentido personal para nosotros. El viejo espectáculo de las imágenes siempre ha cambiado cuando el telón se vuelve a abrir en el escenario y muestra los últimos visual media en cuestión. El espectáculo obliga a su audiencia a aprender nuevas técnicas de percepción y con ello a dominar las nuevas técnicas de representación. Pero el cuerpo sigue siendo una pièce de résistance en contra de unos medios que aparecen y desaparecen a velocidad creciente y acelerada. Esas imágenes que investimos con un significado personal, son diferentes de las muchas que sólo consumimos y olvidamos inmediatamente.

\section{MIXED MEDIA}

Es obvio que los media rara vez se presentan ellos solos y que por lo general existen como lo que se llama un mixed media. Este término, sin embargo, no describe la precisión y complejidad de su interacción. Los media son intermediarios por definición, pero también actúan como intermediarios entre sí y se reflejan, citan, se superponen y corrigen o censuran el uno al otro. A menudo coexisten en capas cuyos caracteres varían de acuerdo con su posición en la historia. Los viejos media no necesariamente desaparecen para siempre, sino, más bien, cambian su significado y su función. El término intermedialidad, por lo tanto, sería más preciso que el de mixed media. La pintura vivía en la fotografía, las películas en la televisión, y la televisión en lo que llamamos los new media del arte visual. Esto significa no solo que percibimos las imágenes en los media, sino también que experimentamos imágenes de los media siempre que los viejos media hayan dejado de cumplir su función principal y se hagan visibles, en una segunda mirada, de una manera en que nunca habían sido.

Marshall McLuhan se ha ocupado de este fenómeno en su convincente ensayo "Environment and Anti-Environment"18. Su afirmación de que un medium se con-

18 Ver Marshall McLuhan, "Environment and Anti-Environment," en Media Research: technology, Art, Communication, ed. Michael A. Moos (New York, 1997). 
vierte en objeto de atención solo después de que ser sustituido por un medium nuevo, que da a conocer su naturaleza en retrospectiva, estimula una serie de conclusiones. Los media actuales disimulan su verdadera estrategia detrás de los efectos de su aparente inmediatez, que sigue siendo su propósito principal. Cabe añadir que nuestras habilidades de percepción también se construyen en capas que nos permiten distinguir media de diferentes tipos y de diferentes épocas. En consecuencia, los medios siguen funcionando, aunque su uso original pertenezca al pasado. Así, los media actuales a veces adoptan una capacidad de almacenamiento, o memoria, cuando administran un archivo electrónico de imágenes que vienen de muy lejos. A veces, los new media parecen espejos recién pulidos de memoria en los que las imágenes del pasado sobreviven, así como hicieron en otras ocasiones en las iglesias, los museos y los libros. Merece especial atención que nos sintamos abordados incluso por imágenes muy antiguas que residen en media obsoletos. Obviamente, no hay ningún automatismo involucrado. Las imágenes albergan y abren una relación compleja con sus media y por lo tanto con nosotros.

En medio de la vorágine y de la velocidad de las imágenes en directo de hoy en día, a menudo observamos las imágenes mudas del pasado con una mirada de nostalgia. Fue una experiencia similar cuando los fieles en la época de la Reforma católica recurrieron a los iconos religiosos, que precedieron a la llegada del arte renacentista ${ }^{19}$. Así, los antiguos iconos se convirtieron en el foco de una nueva puesta en escena, lo que dio lugar a instalaciones barrocas, como enormes retablos a modo de escenas con trasfondo político. Y el cuadro de caballete enmarcado, cuando entró en uso, todavía contenía la memoria del icono, cuya forma básica, un panel móvil y enmarcado, se siguió empleando mientras que cambiaba el significado y la estructura visible en su conjunto. La invención de la imagen en caballete ilustra la complejidad inherente a los visual media, que no se puede reducir ni a los materiales ni a las técnicas ${ }^{20}$. La imagen moderna, junto con la perspectiva que ofreció, fue un invento exclusivamente occidental. Invistió al sujeto humano, que se hizo consciente de sí mismo en ese momento, con imágenes —o, más bien, pictures - que necesitaban de la auto-reflexividad. Se puede decir que la imagen sobre panel era un medium para la mirada, mientras que la fotografía, en la que el cuerpo se graba mecánicamente, en un principio fue recibida como un medium del cuerpo. Esto significaba que el cuerpo crea su propia huella, sin depender ya más de la mirada observadora de un pintor. En la actual puesta en escena de la fotografía digital, la interrelación entre medium, imagen y cuerpo ha cambiado de nuevo drásticamente. La situación es especialmente compleja en las imágenes de una película, que no son vistas en la película en sí, ni fijadas en la pantalla de cine, sino que, como sabemos, llegan a nosotros a través de la proyección y del engaño a un espectador que se apropia de ellas al ritmo doble de la proyección pública y la imaginación personal ${ }^{21}$.

19 Ver Belting, Bild und Kult: Eine Geschichte des Bildes vor dem Zeitalter der Kunst (Munich, 1990); trad. española, Imagen y culto: Una historia de la imagen anterior a la era del arte (Akal, Madrid 2009), cap. 20.

20 Ver Hans Belting y Christiane Kruse, Die Erfindung des Gemäldes: Das erste Jahrhundert der niederländischen Malerei (Munich 1994).

21 Ver Belting, Antropología de la imagen, cap. 3. 


\section{0. ¿IMÁGENES TRADICIONALES?}

Las funciones que se han asignado a la imagen, el medium y el cuerpo han variado constantemente, pero su estrecha interacción continúa hasta nuestros días. El medium, a pesar de su carácter polisémico y su uso polivalente, ofrece la identificación más fácil y por esta razón ha sido favorecido por las teorías contemporáneas. El cuerpo viene a continuación, pero muy claramente y con demasiada frecuencia se ha desarrollado en contra de las tecnologías actuales y ha sido considerado como su anverso. Por lo tanto, se necesita un nuevo énfasis en el cuerpo como medium vivo, capaz de percibir, recordar y proyectar imágenes. El cuerpo, como propietario y destinatario de las imágenes, utilizó los media como extensiones de sus propias capacidades visuales. Los cuerpos reciben imágenes percibiéndolas, mientras que los media las transmiten a los cuerpos. Con la ayuda de máscaras, tatuajes, ropa, y acciones, los cuerpos también producen imágenes de sí mismos o, en el caso de los actores, imágenes que representan a otros, en cuyo caso actúan como media en el sentido más completo y original. Su monopolio inicial en la mediación de imágenes nos permite hablar de los cuerpos como el arquetipo de todos los visual media.

Queda la imagen, el primero de mis tres parámetros, que resulta ser el más difícil de definir. Es más fácil distinguir imágenes a partir de sus media y de sus cuerpos que identificarlas en términos positivos. En este sentido, debemos considerar el dualismo entre imágenes mentales y físicas. Las imágenes no sólo reflejan un mundo externo, sino que también representan las estructuras esenciales de nuestra forma de pensar. Georges Didi-Huberman ha hablado, de modo sorprendente, del "anacronismo" inherente a las images ${ }^{22}$. De hecho, lo que hacen no es solo presentar un anacronismo incómodo en las teorías contemporáneas en las que tanto la tecnología como la medialidad se ven favorecidas. También se comportan de manera anacrónica con respecto al progreso inherente en la historia de unos media con los que no mantienen el ritmo. Günther Anders, ya en la década de 1950, habló irónicamente de los seres humanos como seres anticuados, a los que quería defender por esa misma razón. La búsqueda actual de realidad virtual e inteligencia artificial es una confirmación contundente a este respecto, ya que revela la necesidad de ir más allá de los límites de los cuerpos reales y también, por lo tanto, la de superar a las llamadas imágenes tradicionales .

Lev Manovich afirma que, en la era digital, la imagen tradicional no ha dejado de existir ${ }^{23}$. Pero, ¿qué es una imagen tradicional? ¿Es tradicional simplemente porque todavía interactúa con nuestros cuerpos? ¿O es que todos acusamos demasiado rápido a las imágenes predigitales como meras herramientas de imitación ingenua encargadas de duplicar el mundo visible? ¿Tenía Baudrillard razón cuando distinguió agudamente las imágenes de la realidad y acusó a la práctica de la imagen con-

\footnotetext{
22 Ver Georges Didi-Huberman, Ante el tiempo: historia del arte y anacronismo de las imágenes (Buenos Aires. Adriana Hidalgo, 2006).

23 Ver Lev Manovich, "Eine Archäeologie der Computerbilder", Kuntsforum Internacional 132 (1996): 124. Ver también Manovich, El lenguaje de los nuevos medios (Barcelona. Paidós, 2005), y la crítica de su posición en Anette Hüsch, "Der gerahmte Blick” (Ph.D. I lochschule für Gestaltung, Karlsruhe, 2003).
} 
temporánea de forjar la realidad, como si existiera una realidad totalmente aparte de las imágenes con las que nos la apropiamos? ¿Es posible distinguir las imágenes de la así llamada realidad con tal ingenuidad ontológica? Una trampa de otro tipo nos espera con la tan familiar distinción entre media analógicos y media digitales, analógicos con respecto al mundo que reproducen y digitales con respecto a una supuesta liberación total de cualquier mimesis. Caemos en la trampa cuando simplemente transferimos esta distinción, propia de los media, a las imágenes, con la que no funciona de ninguna manera.

Es una simplificación injusta hablar de las imágenes históricas como meramente imitativas, privándolas por lo tanto de su papel como pilotos para la imaginación colectiva. Vilém Flusser puede ir demasiado lejos cuando en su filosofía de la fotografía habla de las imágenes como "mágicas" y las transfiere a nuestras vidas "donde todo se repite", mientras que en el mundo de la invención todo cambia. Pero tenemos que admitir que está en un camino correcto en este sentido. También mantiene que "las imágenes intervienen entre nosotros y el mundo. Más que representar al mundo, se interponen y provocan que vivamos en función de las imágenes que hemos creado nosotros mismos" 24 . La función retroactiva de la representación, en el sentido más amplio, está, por lo tanto, bien utilizada. Sin embargo, no podemos hablar de las imágenes en sólo un sentido sino, más bien, debemos clasificar imágenes según sus diferentes fines y efectos. Actualmente, las imágenes en el ámbito de la información gozan de una fama inmerecida, como en los dominios del entretenimiento y la publicidad. El entretenimiento, como en las películas, sin embargo, tiene un acceso inmediato a nuestra reserva privada de imágenes, que sigue siendo anacrónica en el sentido de Didi-Huberman. Las imágenes que sirven a nuestro conocimiento son muy diferentes de las que se dirigen a nuestra imaginación.

\section{LA COLONIZACIÓN DE LAS IMÁGENES}

La diferencia entre imagen y medium emerge claramente en un contexto transcultural. Es obvio que media como el cine o la televisión entran fácilmente en diferentes entornos culturales donde las imágenes resultantes, no obstante, continuarán representando una tradición local en particular. Esto se aplica incluso a fotografía, como Christopher Pinney ha demostrado en su libro sobre la fotografía india ${ }^{25}$. Por tanto, no es en absoluto tan evidente que la difusión mundial de los visual media, aunque sus raíces estén en la cultura occidental, cause una propagación mundial de las imágenes occidentales o, menos aún, de la imaginación occidental. Es más probable que ocurriera lo contrario, si las condiciones económicas permitieran otro curso de los acontecimientos.

Las teorías actuales de la imagen, a pesar de sus pretensiones de validez universal, por lo general representan las tradiciones occidentales de pensamiento. Los enfoques que tienen sus raíces en tradiciones no occidentales aún no han entrado en

24 Vilém Flusser, Hacia una filosofía de la fotografía (México. Trillas, 1990), pp. 12-13.

25 Ver Christopher Pinney, Camera Indica: The Social Life of Indian Photographs (London, 1997). 
nuestros territorios académicos, excepto en dominios especiales de la etnología. Y, sin embargo, las imágenes no occidentales han dejado su huellas en la cultura occidental desde hace mucho tiempo. Por lo tanto, me gustaría terminar mi ensayo con dos de estos casos, cuyo recuerdo quizás pueda sustituir a una conclusión imposible. Uno es el primitivismo, que, hace un siglo, dominó la escena del arte de vanguardia. La otra es la colonización de las imágenes mexicanas, hace medio milenio, por los conquistadores españoles.

El Primitivismo respondía al anhelo de un arte ajeno, e incluso un arte superior, donde el arte, en el sentido occidental, nunca había existido. La apropiación exclusivamente formal de máscaras africanas y "fetiches" dio lugar a la percepción de que se separaba a las imágenes de su medium. Picasso y sus amigos nunca reprodujeron ninguna figura africana como tal, sino que, más bien, transfirieron formas africanas a media occidentales tales como la pintura al óleo. Para ser más precisos, los artistas primitivistas sacaron sus propias imágenes de lo que los artefactos africanos parecían y lo reaplicaron al arte modernista. En un primer momento, no se preocuparon por la importancia que las imágenes tenían para los indígenas sino que, abstraídos por esas imágenes que reinterpretaron como estilo, disolvieron la simbiosis original entre imagen y medium. Lo que las imágenes de los artefactos africanos pretendían expresar en su lugar de origen era totalmente diferente de lo que una audiencia occidental identificaría en ellos. En otras palabras, el mismo medium visual transmite imágenes de muy diferentes tipos en la situación original y en la situación occidental. El público occidental no se limitó a malinterpretar lo que veía, sino que también invistió a las obras importadas con sus propias imágenes mentales. Manteniendo este doble proceso de expropiación y reapropiación, el vínculo con los rituales originales se perdió en una doble abstracción: abstracción en términos de la traducción de imágenes al estilo modernista y abstracción en términos de su traslado a la galería de arte 26 .

La colonización de las imágenes indígenas como resultado de la conquista española de México ha sido muy bien analizada por Serge Gruzinski, cuyo libro Images at War ofrece una guía práctica para el tema ${ }^{27}$. Para mi propósito, en este momento histórico se pueden distinguir dos problemas diferentes. El primero es el choque entre conceptos aparentemente incompatibles sobre lo que las imágenes son, lo que causó que los españoles rechazaran la posibilidad de que los aztecas tuvieran algún tipo de imágenes. Los españoles hablaron de las imágenes aztecas como meros objetos extraños, que definían como cerniés* y, por lo tanto, quedaron excluidas de cualquier comparación con sus propias imágenes. El mismo rechazo se aplicaba a la religión nativa, que no sólo parecía una religión diferente, sino que no parecía en absoluto una religión. En realidad, las imágenes de ambos lados representaban a la reli-

\footnotetext{
26 Ver "Primitivism" in Twenieth Century Art: Affinity of the Tribal and the Modern, William Stanley Rubin, ed., (New York, 1984).

27 Ver Serge Gruzinski, La Guerre des images: Christophe Colomb à "Blade Runner" (1492-2019) (Paris, 1990); traducción al castellano como La guerra de las imágenes: de Cristobal Colón a "Blade Runner” (1492-2019) (Fondo de Cultura Económica, México 1994).

* Nota del traductor: se ha respetado el término usado en la versión original del texto, al no encontrar ninguna traducción al castellano completamente satisfactoria.
} 
gión, lo que constituyó una razón adicional para que los españoles no reconociesen más que ídolos o pseudoimágenes en México. En contramedida, la importación de imágenes españolas se convirtió en una parte importante de la política española. Pero para introducir los "iconos" extranjeros en los "sueños" de los indígenas, se necesitaba una colonización mental. Visiones celestiales se impusieron en aztecas seleccionados para garantizar la apropiación de las imágenes importadas, lo que significaba que los cuerpos vivos se involucraron en esa transferencia de imágenes. El proyecto se completó sólo cuando las imágenes importadas también habían tomado posesión de las imágenes mentales de los demás.

El proyecto de los españoles, que se llevó a cabo con implacable entusiasmo, nos permite entender fácilmente la mecánica de la transmisión de imágenes, que nunca escatima la parte mental, pero considera que el verdadero objetivo también en está en el espacio público. Mi último ejemplo parece estar muy alejado de las preocupaciones de actuales, y sin embargo, lo he elegido precisamente por su anacronismo aparente, que no obstante, hace que sea aplicable a mi argumento. No es aplicable a causa de que la colonización de nuestra imaginación aún continúa hoy en día, e incluso sucede dentro de nuestro propio hemisferio, como Augé ha demostrado muy bien en su libro La guerra de los sueños. Es aplicable ya que explica la interacción entre la imagen, el cuerpo y el medium de una manera sorprendente. No fueron solo las imágenes españolas, sino también sus media - lienzos y esculturas- lo que causó resistencia entre los indígenas, cuyos cuerpos (y cerebros) carecían de ninguna experiencia de este tipo.

El arte español fue sin duda partícipe en este evento, ya que el arte, en aquel tiempo, era el único medio visual que existía. Pero los artefactos importados no preocupaban como arte. Tenían importancia sólo como agentes de imágenes de gran importancia. Por lo tanto, sería redundante insistir en el significado político, que es evidente por sí mismo en este caso. Solo el arte en el sentido moderno, un arte con una afirmación de autonomía, atrae actualmente las consabidas controversias sobre determinadas posturas políticas o la falta de sentido político. En nuestro caso, sin embargo, la despolitización de las imágenes indígenas no fue más que otro acto político. Fue solo en España donde los artefactos aztecas llegaron a ser clasificados como arte y se recogieron como tal, con el fin de privarlos de cualquier significado político o religioso y para dejarlos fuera de la circulación de imágenes. No es necesario trazar paralelismos con nuestro tiempo, en el que el arte es constantemente neutralizado por la mercado del arte.

Originalmente, la iconología, en términos de la historia del arte, se limitó solo al arte. En la actualidad, es tarea de una nueva iconología establecer un vínculo entre el arte y las imágenes en general, pero también de reintroducir el cuerpo, que, o bien ha sido marginalizado por nuestra fascinación por los media, o se ha vuelto un extraño en nuestro mundo. El actual consumo masivo de imágenes necesita nuestra respuesta crítica, que a su vez necesita de nuestras ideas sobre el trabajo que las imágenes hacen en nosotros. 


\title{
RESUMEN
}

El autor propone un nuevo tipo de iconología no limitado a las imágenes artísticas, que tiene en consideración la aparición de las imágenes dese un punto de vista a la vez fenomenológico y pragmático, indicando que las imágenes suceden en la cultura. Según este enfoque, las representaciones internas y externas, o imágenes mentales y físicas, pueden ser consideradas como caras de una misma moneda. No hay imágenes visibles que nos lleguen sin mediación. Los médium son esenciales en la conformación y creación de las imágenes. Los cuerpos (es decir, el cerebro) funcionan como un medium vivo que nos hace percibir, proyectar o recordar imágenes y que también permite a nuestra imaginación censurarlas o transformarlas. Imagen, medio y cuerpo constituyen una constelación triádica, que admite una cuidadosa consideración. La historia de los media visuales, y de los otros media, es la historia de la cultura. Las imágenes digitales se dirigen normalmente a la imaginación de nuestros cuerpos y cruzan la frontera entre imágenes visuales e imágenes virtuales, imágenes vistas e imágenes proyectadas.

Palabras clave: imágenes, icono, iconología, médium, media visuales, intermedialidad, cuerpo.

\section{Image, Medium, Body: a New Approach to Iconology}

\begin{abstract}
The author proposes a new kind of Iconology, not limited to the artistic images, which takes into account the appearance of the images from a phenomenological and pragmatic view, indicating that images happen in culture. Under this approach, the internal and external representations, or mental and physical images, may be considered as faces of the same coin. No visible images reach us unmediated. The mediums are essential in shaping and creating images. The bodies (ie, the brain) function as a living medium that makes us perceive, project, or remember images and that also enables our imagination to censor them or transform them. Image, medium and body constitute a triadic constellation, which demands careful consideration. The history of the visual media, is the history of culture. Digital images usually address our bodies imagination and cross the border between visual images and virtual images, images seen and projected images.
\end{abstract}

Keywords: pictures, icon, iconography, medium, visual media, intermediality, body.

\section{RÉSUMÉ}

L'auteur propose un nouveau type d'iconologie pas limité à des images artistiques, qui prend en compte l'aspect des images à la fois phénoménologique et pragmatique, ce qui indique que les images arrivent dans la culture. Selon cette approche, les représentations internes et externes, ou les images mentales et physiques, peuvent être considérées comme des faces de la même médaille. Aucune image nous parvient sans intermédiaire. Les médiums sont essentiels dans la formation et la création d'images. Les organismes (par exemple, le cerveau) fonctionnent comme un milieu qui nous fait percevoir, projetter, ou se rappeler les images et qui permet aussi de notre imagination puisse les censurer ou les transformer. Image, médium et corps constituent une constellation triadique, qui demande un examen attentif. L'histoire des médias visuels, est l'histoire de la culture. Les images digitales portent habituellement sur notre imagination et traversent la frontière entre les images visuelles et des images virtuelles, images vues et projetées des images.

Mots-clé: photos, icône, iconographie, médium, médias visuels, intermédialité, corps. 